\title{
THE MICROSTRUCTURE AND MECHANICAL PROPERTIES OF CEMENTITIOUS MATERIALS COMPRISED OF LIMESTONE, CALCINED CLAY AND CLINKER
}

\author{
LI QINFEI*,**,***, WANG HAN***, ${ }^{*}$ HOU PENGKUN*,**, CHEN HENG*,**, \\ ${ }^{\#}$ WANG YANG $*, * *$, CHENG XIN*,** \\ *Shandong Provincial Key Laboratory of Preparation and Measurements of Building Materials, University of Jinan, \\ Jinan, 250022, China \\ **Department of Materials Science and Engineering, University of Jinan, \\ Jinan, 2500222, China \\ ***State Key Laboratory of Green Building Materials, \\ Beijing, 100024, China \\ "E-mail: pkhou@163.com
}

Submitted March 14, 2019; accepted June 23, 2019

\begin{abstract}
Keywords: Calcined clay, Limestone, Mechanical properties, Microstructure
Limestone, calcined clay and cement $\left(L C^{3}\right)$ are one of the low carbon cement materials which are used as a partial substitution of clinker and Portland cement. In this study, the effects of limestone and calcined clay $\left(L C^{2}\right)$ on the mechanical properties and microstructure of mortars were studied under multi-scales. It could be concluded that the compressive strength decreased slightly with an increase in the $L C^{2}$ content, but the flexural strength increased significantly due to the greater formation of crystalline aluminates in the $L C^{3}$. The $x$-ray diffraction and thermal analysis results prove the pozzolanic activity of the calcined clay in the $L C^{3}$ system which is in agreement with the results of the decreasing calcium hydroxide and the increasing ettringite content, and the $\mathrm{LC}^{2}$ could reduce the heat of the hydration of the $L C^{3}$ significantly. Also, the formation of calcium hemicarboaluminate $\left(3 \mathrm{CaO} \cdot \mathrm{Al}_{2} \mathrm{O}_{3} \cdot \mathrm{Ca}\left[(\mathrm{OH})\left(\mathrm{CO}_{3}\right) \mathrm{O} .5\right] \cdot \mathrm{xH}_{2} \mathrm{O}\right)$ and calcium monocarboaluminate $\left(3 \mathrm{CaO} \cdot \mathrm{Al}_{2} \mathrm{O}_{3} \cdot \mathrm{CaCO}_{3} \cdot \mathrm{xH}_{2} \mathrm{O}\right)$, as well as the pozzolanic activity of the calcined clay contributed to the development of the mechanical strength.
\end{abstract}

\section{INTRODUCTION}

Cement is a necessary material for the construction of the infrastructure in our society. The $\mathrm{CO}_{2}$ emissions during the manufacturing of cement account for $8 \%$ of the greenhouse gases across the world. As global warming intensifies, it is urgent to reduce the carbon emissions of the cement industry. There is a practical approach to partially replace clinker and cement with supplementary cementitious materials (SCMs). SCMs have a pozzolanic reactivity leading to a reaction with the cement hydration products, to the improvement of the compactness of the cementitious materials, and to the enhancement of the mechanical properties and durability of the cementitious materials.

With the continuous development of the cement industry, conventional SCMs such as fly ash and slag have been exposed as having many disadvantages. Cement and concrete structures with a high blending volume of fly ash have a prolonged setting time and lower early strength [16]. Also, there are many dis-advantages such as the high prices, a shortage of resources, and performance instability. In order to meet the requirements of lowcarbon emissions in the cement industry, it is necessary to develop new sustainable SCMs with stable quality, abundant reserves and high reactivity.
Limestone, calcined clay and clinker $\left(\mathrm{LC}^{3}\right)$ is a combination of clinker, low-quality calcined clay, limestone and gypsum. Calcined clay is a high pozzolanic reactivity material, at the temperature of the highest pozzolanic reactivity (Clay A: $700-800{ }^{\circ} \mathrm{C}$; Clay B: $800{ }^{\circ} \mathrm{C}$ ) kaolinite and montmorillonite were reported to be completely dehydroxylated [7]. Scrivener et al. reported that the optimal calcination temperature was between $700{ }^{\circ} \mathrm{C}$ and $850{ }^{\circ} \mathrm{C}$ [30]. Temperatures of $750{ }^{\circ} \mathrm{C}$ and $850{ }^{\circ} \mathrm{C}$ were compared [29], and the clay calcined at $850{ }^{\circ} \mathrm{C}$ had a better mechanical strength. Limestone powders have a physical filling effect which can make the cement and concrete structure more compact, and in turn improves the mechanical properties and the durability of the cement and concrete. The lower calcination temperature of the calcined clay and the abundant limestone powder together decreases the emissions of carbon dioxide $\left(\mathrm{CO}_{2}\right)$ in the cement industry. Therefore, $\mathrm{LC}^{3}$ is a promising novel low-carbon cement for the $21^{\text {st }}$ century. The pozzolanic activity of the calcined clay depends on the calcination temperature [3-5], which can react with the calcium hydroxide to form calcium (aluminate) silicate hydration $(\mathrm{C}-\mathrm{A}-\mathrm{S}-\mathrm{H})$. Besides, metakaolin in the calcined clay can also react with gypsum generating ettringite with needle-like crystals [6]. 
The pozzolanic activity and the filling effect of $\mathrm{LC}^{2}$ can effectively reduce the porosity of cement-based materials, and increase the mechanical properties [10-12]. Moreover, the pozzolanic activity of $\mathrm{LC}^{3}$ also improves the interfacial transition zone (ITZ) between the cementitious pastes and aggregates [13-16]. Limestone in the $\mathrm{LC}^{3}$ is more conducive to the improvement of the cement-based material properties due to its filling effect and pozzolanic free-activity. Limestone does not promote the strength of the cement-based materials in the late period, but increases the stiffness and durability of the concrete [20-21,23]. Considering its filling effect, limestone can be packed closely with calcined clay and clinker by filling the voids in the concrete for improving the distribution of all the particles in the $\mathrm{LC}^{3}$ cement [17-19]

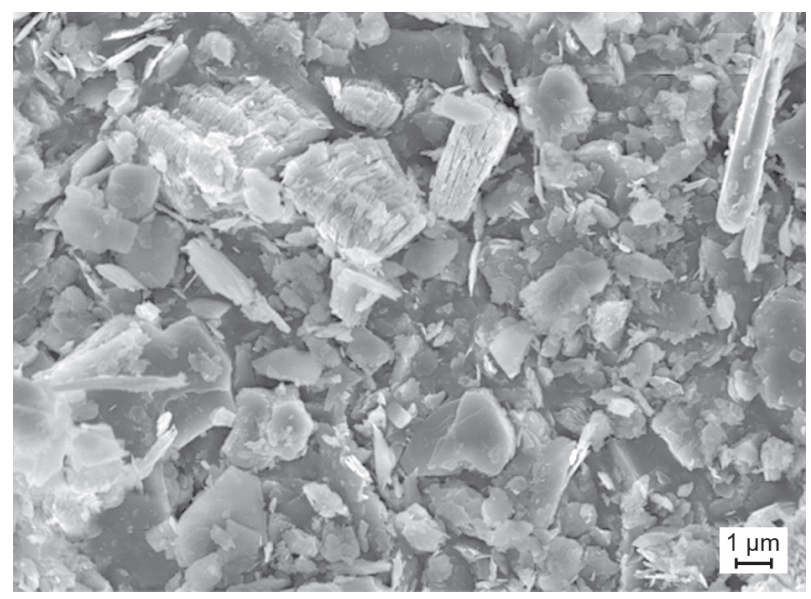

a) metalaokin

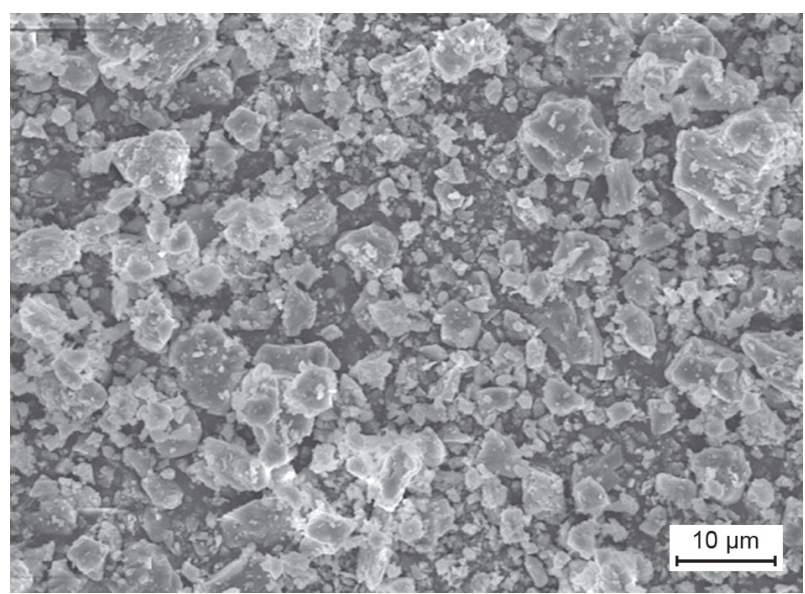

b) limestone
In Europe, India and South America, $\mathrm{LC}^{3}$ has been studied for several years, but the exploration of $\mathrm{LC}^{3}$ in China is still in its infancy. The quality and composites of the clays in China are quite different from those overseas. And $\mathrm{LC}^{3}$ is relatively complex, as it yields a wide variety of hydration products. Therefore, in this paper, the microstructure of $\mathrm{LC}^{3}$ after hydration was studied through various techniques, which possibly provides a theoretical basis for the practical application of $\mathrm{LC}^{3}$ in China in the future.

\section{EXPERIMENTAL}

\section{Raw materials}

Low-quality clays were purchased from Maoming city, Guangdong province. The experimental calcined clays are prepared by heating in a muffle furnace with the heating rate of $5{ }^{\circ} \mathrm{C} \cdot \mathrm{min}^{-1}$, and are kept at the temperatures of $800{ }^{\circ} \mathrm{C}$ for 1 hour [29]. The chemical composites of the calcined clay are shown in Table 1. The mean diameter of the ground calcined clay is 19.32 $\mu \mathrm{m}$, while its specific surface area is up to $358 \mathrm{~m}^{2} \cdot \mathrm{kg}^{-1}$. The limestone was purchased from Jinan city, Shandong Province, and was ground for 30 minutes. The mean diameter of the ground limestone is $8.26 \mu \mathrm{m}$, while the specific surface area is up to $574 \mathrm{~m}^{2} \cdot \mathrm{kg}^{-1}$.

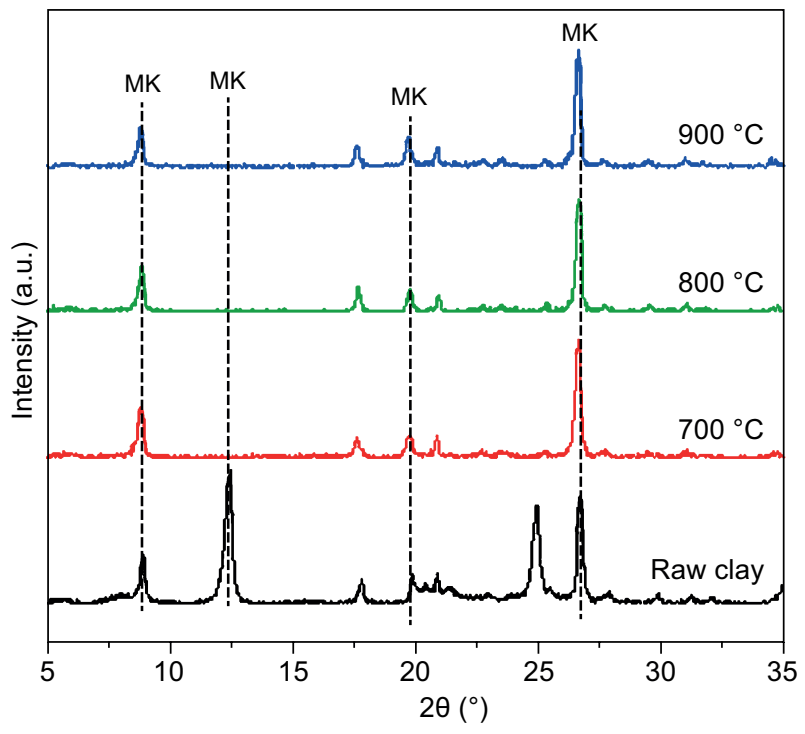

c) XRD patterns

Figure 1. The morphology and XRD patterns of the raw materials: a) calcined clay, b) limestone, c) the XRD patterns of the clay (B) and the calcined clay at $700{ }^{\circ} \mathrm{C}(\mathrm{A} 700), 800{ }^{\circ} \mathrm{C}(\mathrm{A} 800)$ and $900{ }^{\circ} \mathrm{C}(\mathrm{A} 900)$.

Table 1. The composition of the calcined clay and limestone (mass fraction/\%).

\begin{tabular}{lccccccc}
\hline Components & $\mathrm{CaO}$ & $\mathrm{SiO}_{2}$ & $\mathrm{Al}_{2} \mathrm{O}_{3}$ & $\mathrm{~K}_{2} \mathrm{O}$ & $\mathrm{Fe}_{2} \mathrm{O}_{3}$ & $\mathrm{TiO}_{2}$ & LOI* $^{*}$ \\
\hline Calcined Clay & - & 47.97 & 33.22 & 3.09 & 2.10 & 2.25 & 11.19 \\
Limestone & 54.01 & 2.38 & 0.70 & 0.40 & 0.69 & 0.07 & 35.31 \\
\hline
\end{tabular}

* Loss on ignition 
It can be seen in Figure 1 that the calcined clay particles contain a great deal of plate-like and layered metakaolin, which is rich in alumina and silica. Highquality limestones with uniform size were selected and fully pulverised in a KEQ-4L planetary ball mill. The pulverised materials were passed through a sieve of 200 mesh, and the chemical composites of the ground calcined clay and the ground limestone are shown in Table 1. The components of the ground limestone were determined by X-ray fluorescence spectrometry (XRF).

Chinese Grade 42.5 Portland cement was used in the study, purchased from China United Cement Corporation. The International Organization for Standardization (ISO) standard sands were used as the fine aggregates, purchased from Xiamen ISO standard sand co., LTD. A polycarboxylic acid superplasticizer, which is produced by Shandong Zhuoxing Chemical CO. LTD, was used to control the workability of the mortar pastes.

\section{Sample preparation}

The limestone and calcined clay $\left(\mathrm{LC}^{2}\right)$ are mixed by the 2:1 mass ratio of calcined clay to limestone. Studies about the $\mathrm{LC}^{3}$ systems have been derived from European, South American, Indian researchers, while the $\mathrm{LC}^{3}$ system is still at a beginning stage in China. The optimal ratio of 2:1 of the calcined clay to limestone has been approved, and the amount of gypsum fluctuates between $5 \%$ and $8 \%[1-3,7]$. The mixture design of the limestone, calcined clay and cement $\left(\mathrm{LC}^{3}\right)$ and gypsum are shown in Table 2. The substitutions of $\mathrm{LC}^{2}$ are respectively $60 \%, 50 \%$ and $40 \%$ by the mass of the cementitious materials. Gypsum was used in the mixtures by $5 \%$ of the mass of the cementitious materials. A polycarboxylic acid superplasticizer is used at $0.05 \%$ of the mass of the cementitious materials to control the workability.

The $\mathrm{LC}^{3}$ pastes were prepared by a mixer with the water-to-binder ratio of 0.5 , and transferred into plastic pipes in a standard curing chamber with a temperature of $21^{\circ} \mathrm{C}$ and a humidity of $95 \%$. The $\mathrm{LC}^{3}$ pastes were cured for $1 \mathrm{~d}, 3 \mathrm{~d}, 7 \mathrm{~d}$ and $28 \mathrm{~d}$. The hydration of the $\mathrm{LC}^{3}$ samples was stopped by ethanol, and then the samples were transferred into a vacuum oven for drying. Afterwards, all the samples were stored in a nitrogen atmosphere to avoid carbonation. X-ray diffraction, scanning electronic microscope and calorimetry are performed to study the $\mathrm{LC}^{3}$ microstructure.

Table 2. Mix proportion of the $\mathrm{LC}^{3}$ mortars with 0.5 of waterto-binder ratio and 2:1 mass ratio of calcined clay-to-limestone

\begin{tabular}{lcccc}
\hline NO. & $\begin{array}{c}\text { Cement } \\
(\mathrm{g})\end{array}$ & $\begin{array}{c}\text { Calcined clay } \\
(\mathrm{g})\end{array}$ & $\begin{array}{c}\text { Limestone } \\
(\mathrm{g})\end{array}$ & $\begin{array}{c}\text { Gypsum } \\
(\mathrm{g})\end{array}$ \\
\hline OPC & 450 & 0 & 0 & 0 \\
$\mathrm{~B} 40$ & 270 & 120 & 60 & 22.5 \\
$\mathrm{~B} 50$ & 225 & 150 & 75 & 22.5 \\
$\mathrm{~B} 60$ & 180 & 180 & 90 & 22.5 \\
\hline
\end{tabular}

Based on the Chinese National Standard "GB/T 17671 ", the $\mathrm{LC}^{3}$ mortars were prepared with the water-to-binder ratio of 0.5 in Table 2. $1350 \mathrm{~g}$ of the ISO standard sands are used in the $\mathrm{LC}^{3}$ mortars. The fresh $\mathrm{LC}^{3}$ mortars are cast into steel moulds with dimensions of $40 \mathrm{~mm} \times 40 \mathrm{~mm} \times 160 \mathrm{~mm}$. After vibrating for 60 times, these specimens were cured for $1 d, 3 d, 7 d$ and $28 \mathrm{~d}$ under the standard curing conditions mentioned above. The compressive and flexural strength of the $\mathrm{LC}^{3}$ mortars were measured at different curing ages.

Test methods

\section{Mechanical properties}

Based on the Chinese standard GBT17671-2005, the CMT5504 universal mechanical and electrical testing machine and CDT 1305-2 mechanical and electrical compression testing machine (MTS Systems (China) Corporation, China) were used to test the compressive strength of the cement mortar.

\section{Active silica content measurement}

According to the Chinese standard GB/T 176-2008 for determining the active silica content, the potassium fluorosilicate volumetric method was used in this experiment. The procedures are: 1) $0.5 \mathrm{~g}$ of calcined clay reacts with $200 \mathrm{ml}$ of saturated $\mathrm{Ca}(\mathrm{OH})_{2}$ solution under $100{ }^{\circ} \mathrm{C}$ for 2 hours; 2) to use $\mathrm{HCl}(36 \%)$ to dissolve the crystalline silica from the calcined clay; 3 ) After filtering, the filtrate is titrated by $200 \mathrm{~g} \cdot \mathrm{l}^{-1}$ of an $\mathrm{Na}(\mathrm{OH})_{2}$ solution. The measurement for the active silica in the calcined clay was conducted three times, and an average value was calculated.

\section{Heat release}

An isothermal calorimeter from TA instruments (TAM Air) was used to measure the heat release of the samples. $2 \mathrm{~g}$ of paste was put into a glass ampoule, then sealed and put in the isothermal calorimeter. The environmental temperature was set to $25{ }^{\circ} \mathrm{C}$ during the tests. After reaching the initial thermal equilibrium state, water was injected by injector into the ampoules to record the initial data.

\section{Thermogravimetric analysis (TGA)}

The cement pastes with different curing ages were ground and sieved through a 200-mesh sieve and approximately $35 \sim 50 \mathrm{mg}$ was prepared for the TGA test. The thermogravimetric analyses (TGA) are performed with a Mettler Toledo TGA/DSC 1 instrument. The cement powder was heated from $30{ }^{\circ} \mathrm{C}$ to $1000{ }^{\circ} \mathrm{C}$ in a nitrogen atmosphere. The $\mathrm{Ca}(\mathrm{OH})_{2}$ and $\mathrm{CaCO}_{3}$ content of the pastes was determined by TGA using the tangent method. 
Phase analysis (XRD)

The hardened samples with different curing times were ground and then passed through a 200 mesh. An X-ray diffraction (XRD) from a Bruker AXS D8 ADVANCE with a $40 \mathrm{kV}$ X-ray tube (CuKo-target) was used to test the diffraction angle from $5-80^{\circ}$ with a step size of $0.02^{\circ} \cdot \mathrm{s}^{-1}$.

\section{Microstructure analysis (SEM)}

A JSM-7610F Field Emission Gun-Scanning Electron Microscopy equipped with an Oxford X-MaxN $50 \mathrm{~mm}^{2}$ was used to observe the samples' morphology. The samples were dried in a vacuum drier for $48 \mathrm{~h}$ and, gold was sprayed on the surface afterwards, they were analysed at different magnifications.

\section{RESULTS AND DISCUSSION}

\section{Active silica content of calcined clay}

The content of the active $\mathrm{SiO}_{2}$ in the calcined clay with the different calcined temperatures $\left(700^{\circ} \mathrm{C}, 800^{\circ} \mathrm{C}\right.$, $900{ }^{\circ} \mathrm{C}$ ) is shown in Figure 2. The total content of the $\mathrm{SiO}_{2}$ in the XRF test is up to $47.97 \%$ in the clay calcined at $800{ }^{\circ} \mathrm{C}$, while the active $\mathrm{SiO}_{2}$ accounts for approximately $20 \%$ of the total content. As is shown in Figure $2,800^{\circ} \mathrm{C}$ is the optimal temperature for the calcination of the clay, which is in accordance with the studies by Scrivener et al $[1,3]$. Under a calcination temperature of $700{ }^{\circ} \mathrm{C}$, the calcined clay contains a certain content of the active silica. However, a calcination temperature of $700{ }^{\circ} \mathrm{C}$ is not sufficient to complete the dehydration reaction of the clay [2]. On the other extreme end, $900{ }^{\circ} \mathrm{C}$ can cause the calcined clay to recrystallise which leads to a reduction in the activity of the calcined clay. Therefore, $800{ }^{\circ} \mathrm{C}$ is used as the optimal and economical calcination temperature of the clay in the study.

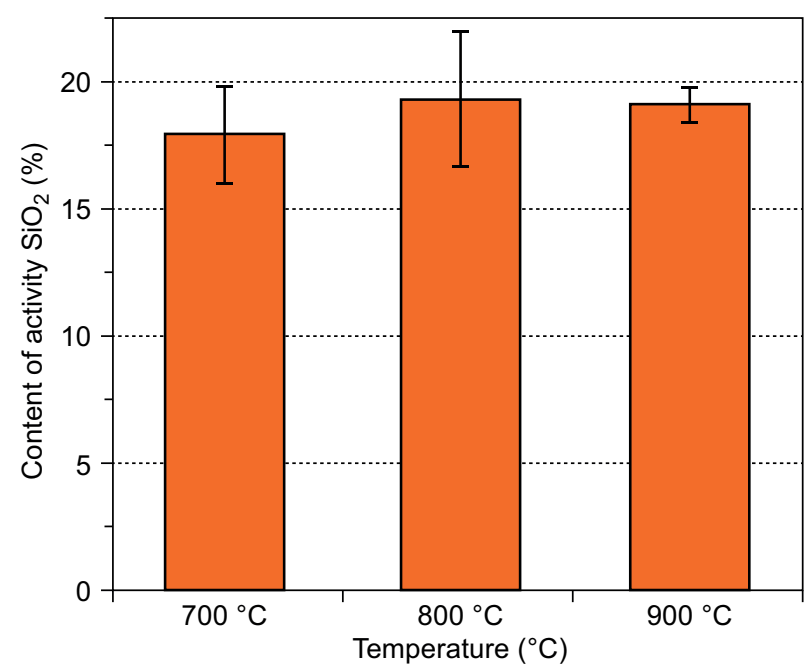

Figure 2. The calcined clay activity test results.

\section{Mechanical properties}

The mechanical properties of the $\mathrm{LC}^{3}$ are shown in Figure 3. At 3 days, the flexural strengths of the $\mathrm{LC}^{3}$ mortars are lower than the control group. The flexural strength of B40 ( $\mathrm{LC}^{2}$ content of $40 \%$ ) is $34.6 \%$ lower than the control group. However, the flexural strength of the $\mathrm{LC}^{3}$ mortars grows more quickly with the hydration time. At 7 days, the flexural strength of the $\mathrm{LC}^{3}$ mortars is close to that of the control group, while the 28-day flexural strength of the $\mathrm{LC}^{3}$ mortars are higher than that of the control group, especially the specimen with the 40 wt. \% LC LC $^{2}$ which is $20 \%$ higher than the control.

The compressive strength of the $\mathrm{LC}^{3}$ mortars is as low as half of the control group at 3 days due to the high substitution and the dilution effect (the reduction of the cement in the samples). The compressive strength of the $\mathrm{LC}^{3}$ mortars increases up to $88 \%$ of the control group, hence displaying a faster growth rate at 7 days. The addition of $\mathrm{LC}^{2}$ can lead to a decrease in the compressive strength of the mortars due to the dilution effect of the $\mathrm{LC}^{2}$. At 28 days, the compressive strength of the $\mathrm{LC}^{3}$ mortars are still lower than the control group. Compared to the B40, B50, B60 group, the compressive strength decreases with the increasing content of $\mathrm{LC}^{2}$, and the compressive strength of the B60 mortar is $23 \%$ lower than that of the B40 mortar.

The compressive strength of all the $\mathrm{LC}^{3}$ mortars is lower than the control group; since the activity of the calcined clay depends primarily on the content and the composition of the active silica, as well as its fineness and its calcination. Some studies $[1,30]$ have shown that fine calcined clay with a high specific surface area certainly has a higher pozzolanic activity, but the specific surface area of the calcined clay in this study is insufficient due to the inadequate grinding, resulting in the reduction of the mechanical properties in the $\mathrm{LC}^{3}$ mortars. Besides, the mechanical properties of the $\mathrm{LC}^{3}$ mortars and concrete depend on the content of the metakaolin in the raw clay [2], whereas the raw clay in this study is of low-quality clay tailings.

However, the 7-day and 28-day flexural strength of all the $\mathrm{LC}^{3}$ mortars are higher than those of the control group, indicating that the calcined clay has the great capability of improving the ductility of the cement-based materials. Since the calcined clay possesses a certain pozzolanic activity for consuming the $\mathrm{Ca}(\mathrm{OH})_{2}$ in the hydration products [5], calcium alumina silicate hydrates $(\mathrm{C}-\mathrm{A}-\mathrm{S}-\mathrm{H})$ can be formed in the $\mathrm{LC}^{3}$ system. The greater generation of $\mathrm{C}-\mathrm{A}-\mathrm{S}-\mathrm{H}$ and crystalline calcium aluminate phases possibly promotes the improvement of the flexibility of the mortars. Therefore, the next section discusses the relationship between the mechanical properties and the microstructure of the $\mathrm{LC}^{3}$ from the aspect of the chemical composites. The microstructure of the $\mathrm{LC}^{3}$ system is much more complicated, and it is important for understanding the performance of this blended cement. 


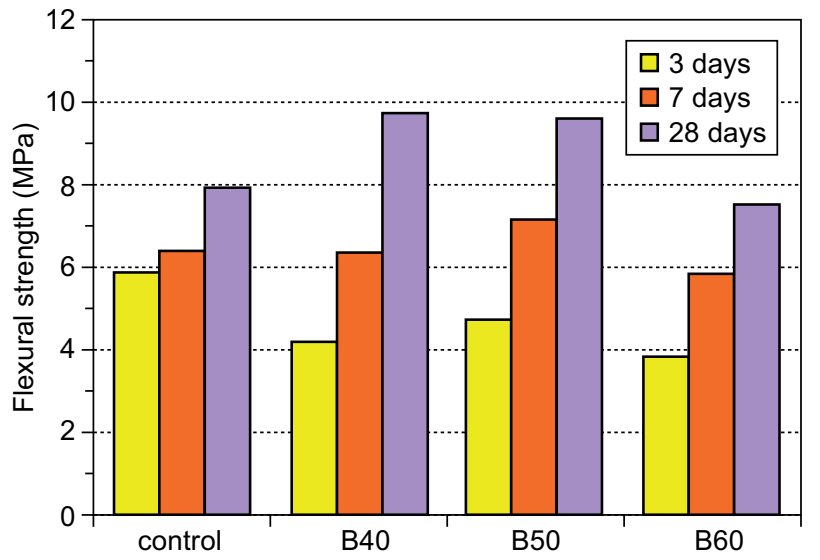

a)

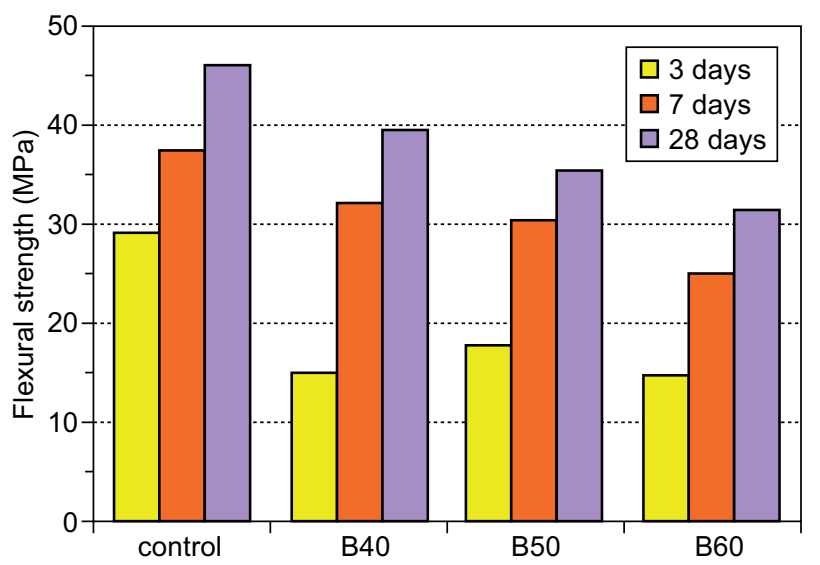

b)

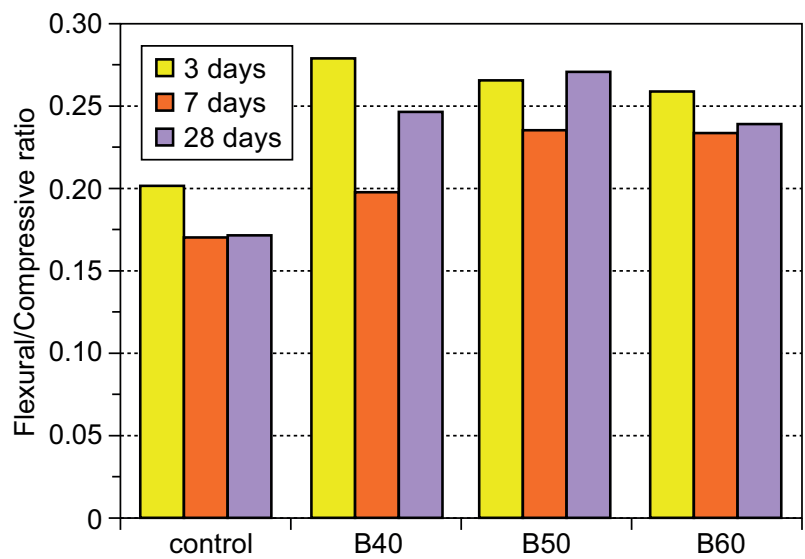

c)

Figure 3. The effect of $\mathrm{LC}^{2}$ on the mechanical properties of the $\mathrm{LC}^{3}$ mortars: a) flexural strength; b) compressive strength; c) flexural/compressive ratio.

\section{Analysis of the chemical composition}

The XRD patterns in Figure 4 show the formation of calcium hydroxide, calcite, AFm phases, and ettringite in each sample at different times. There is also a great deal of quartz in the calcined clay due to the crystalline silica in the raw clay. The calcined clay is rich in active alumina and silica, which can react with the hydration product,
$\mathrm{Ca}(\mathrm{OH})_{2}$, to form the $\mathrm{C}-\mathrm{S}-\mathrm{H} / \mathrm{C}-\mathrm{A}-\mathrm{S}-\mathrm{H}$ gel [25]. The limestone reacts with the active alumina from $\mathrm{C}_{3} \mathrm{~A}$ and the calcined clay to form hemicarboaluminate $(\mathrm{Hc})$ and monocarboaluminate (Mc) [26]. The $\mathrm{SO}_{4}{ }^{2-}$ in ettringite and monosulfoaluminate (Ms) can be replaced easily by the carbonate ions in the limestone [31], to generate hemicarboaluminate $(\mathrm{Hc})$ and monocarboaluminate (Mc) [26]. These carboaluminates have the capability of improving the mechanical properties of the $\mathrm{LC}^{3}$ mortars [31] due to the good stability of the monocarboaluminate and Strätlingite $[32,20]$. The changes in the mechanical properties of the $\mathrm{LC}^{3}$ mortars are affected by the transformation between ettringite and $\mathrm{Ms}$ and by the formation of the hemi/mono-carboaluminates. The framework of these needle-like and plate-like crystals possibly greatly improves the flexural strength. Besides, the alumina and silica in the calcined clay can react with the cement $\mathrm{Ca}(\mathrm{OH})_{2}$ to generate the $\mathrm{C}-\mathrm{A}-\mathrm{S}-\mathrm{H}$ gel, which brings about the development of the strength in the mortars.

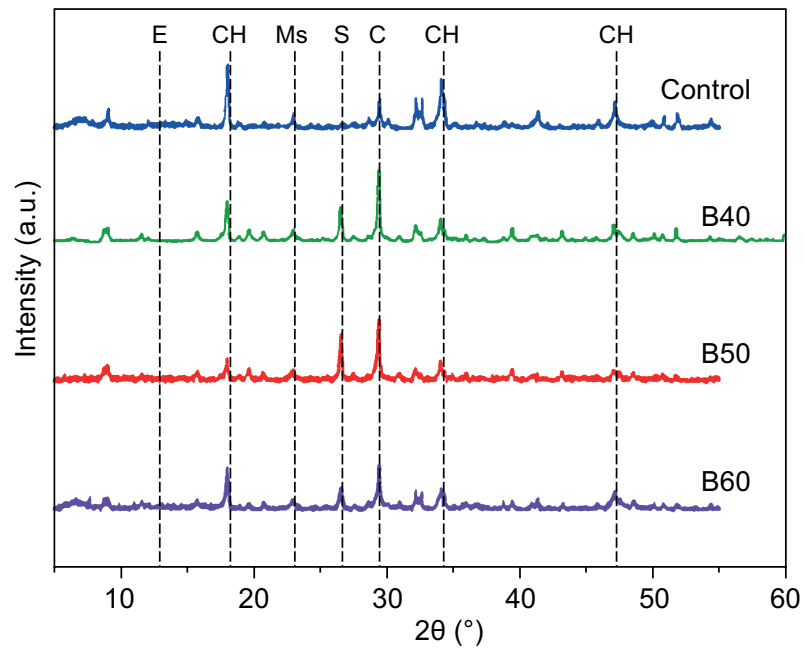

a) 1 day

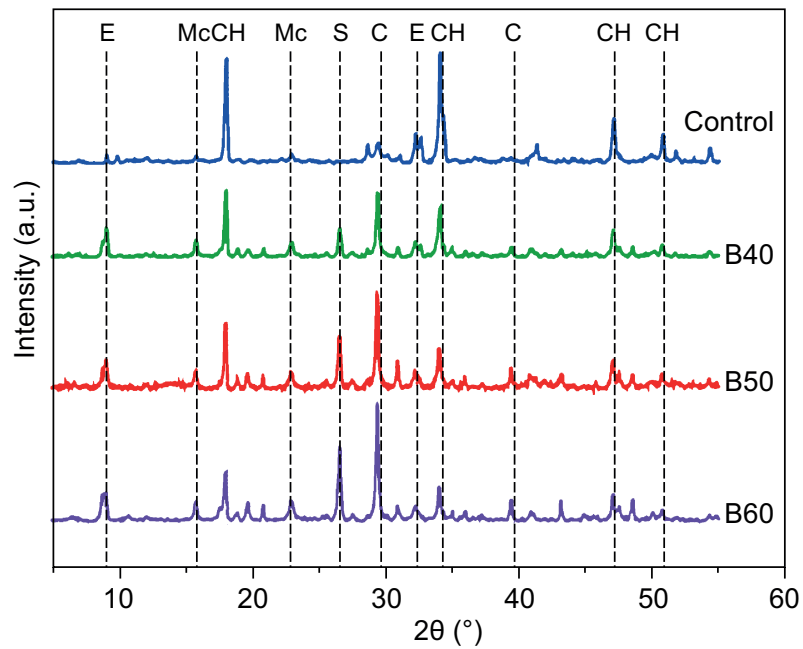

b) 3 days

Figure 4. The XRD patterns for the cement mortar (control group) and the LC3 mortars: a) $1 \mathrm{~d}$; b) $3 \mathrm{~d}$. (Continue on next page) 


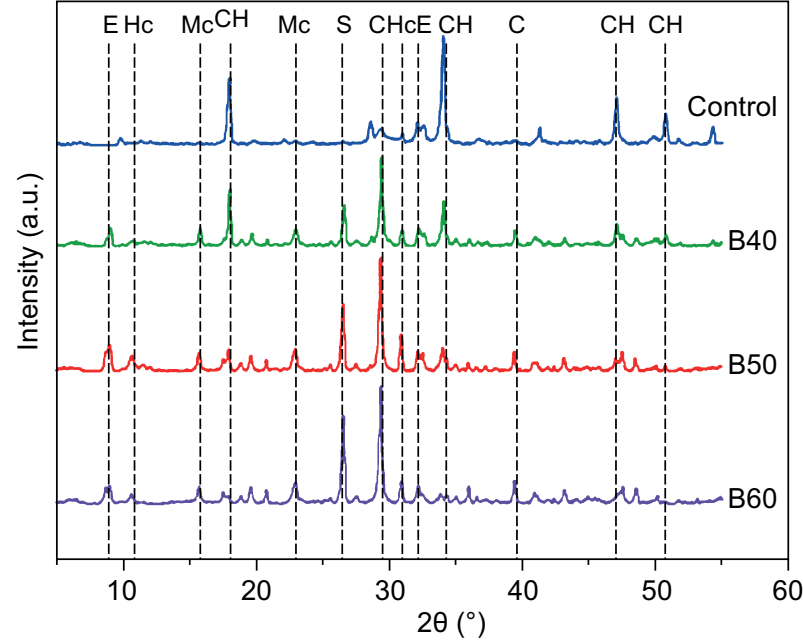

c) 7 days

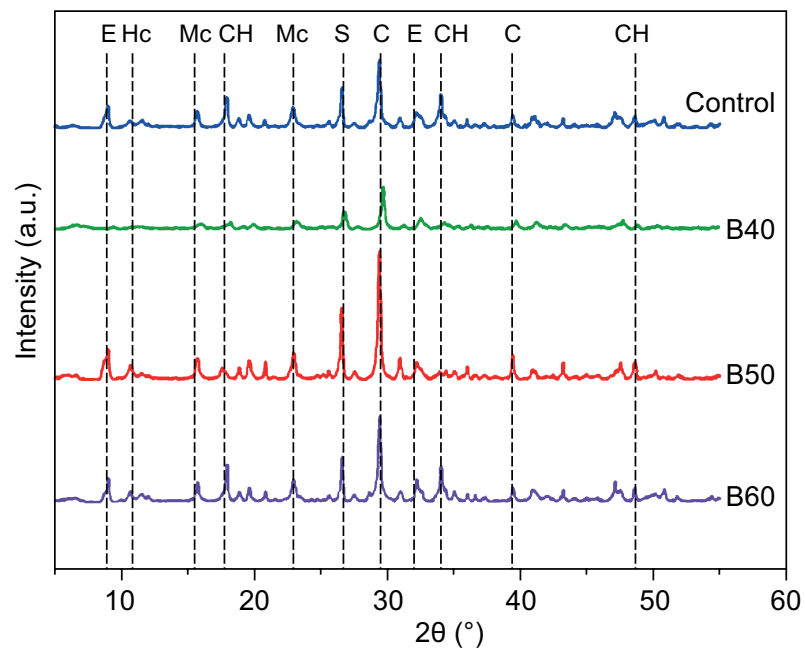

d) 21 days

Figure 4. The XRD patterns for the cement mortar (control group) and the LC3 mortars: c) 7d; d) $28 \mathrm{~d}$.

\section{Thermal analysis}

The thermogravimetric measurement is performed to characterise the reactivity of the calcined clay and limestone. The samples were dried in a vacuum oven and stored in a nitrogen atmosphere to avoid carbonisation. As shown in Figure 4, the content of the calcium carbonate in the OPC samples was nearly zero, indicating that the samples were barely carbonated. In Figure 4, the $\mathrm{Ca}(\mathrm{OH})_{2}$ content decreased quickly at 1 day, but the rate of the pozzolanic reaction is higher at 7 and 28 days. That can explain why the strength of the $\mathrm{LC}^{3}$ system increased faster at 7 days. $\mathrm{CaCO}_{3}$ does not participate in the early hydration reaction.

The thermal analysis results of the $\mathrm{LC}^{3}$ system with varying $\mathrm{LC}^{2}$ content and control (OPC) is shown in Figure 4. The first peak is around the heat release peak of the cement dissolution. The second peak is merged together with the cement and calcined clay hyd- ration [1], since the calcined clay and the limestone can provide some nucleation sites for the formation of $\mathrm{C}-\mathrm{S}-\mathrm{H}$ [25]. In Figure 5c, the third peak at the 30-hour hydration mark is assigned to the reaction of the calcium

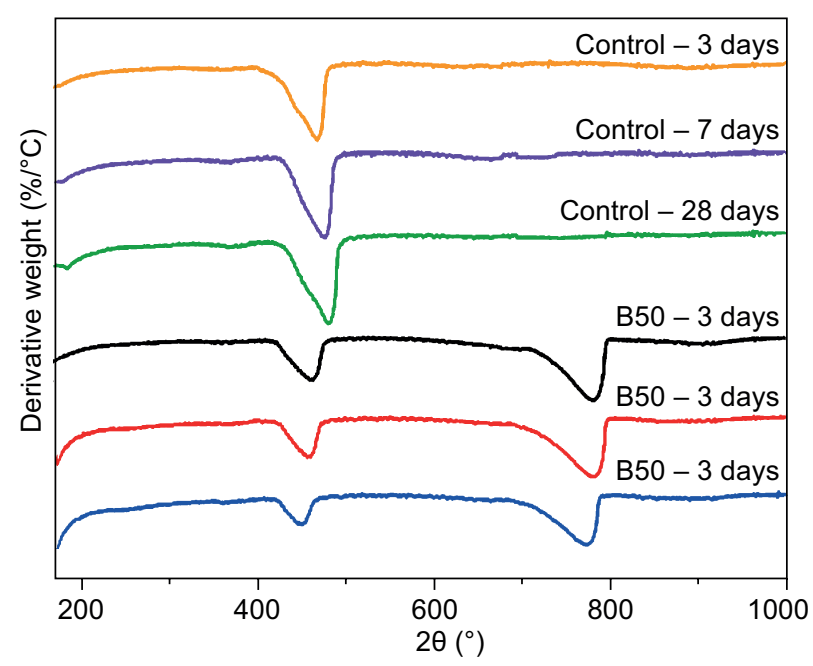

a)

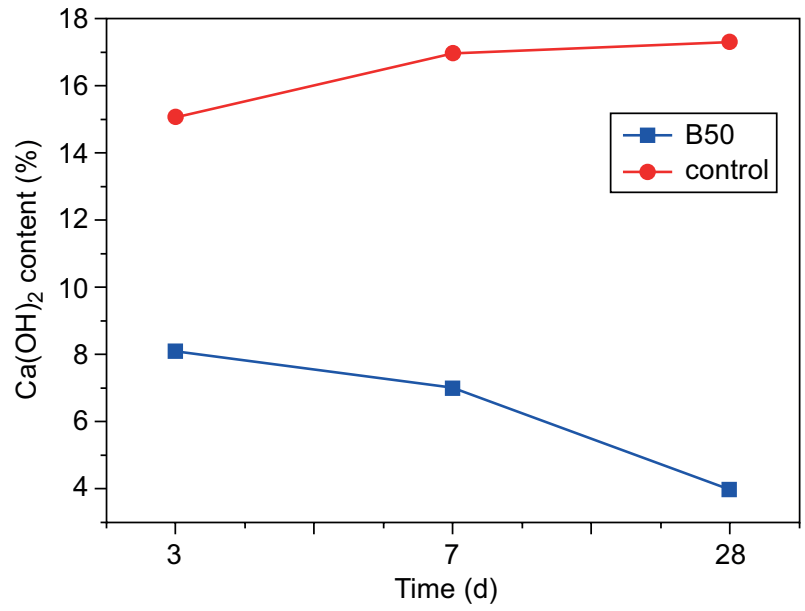

b)

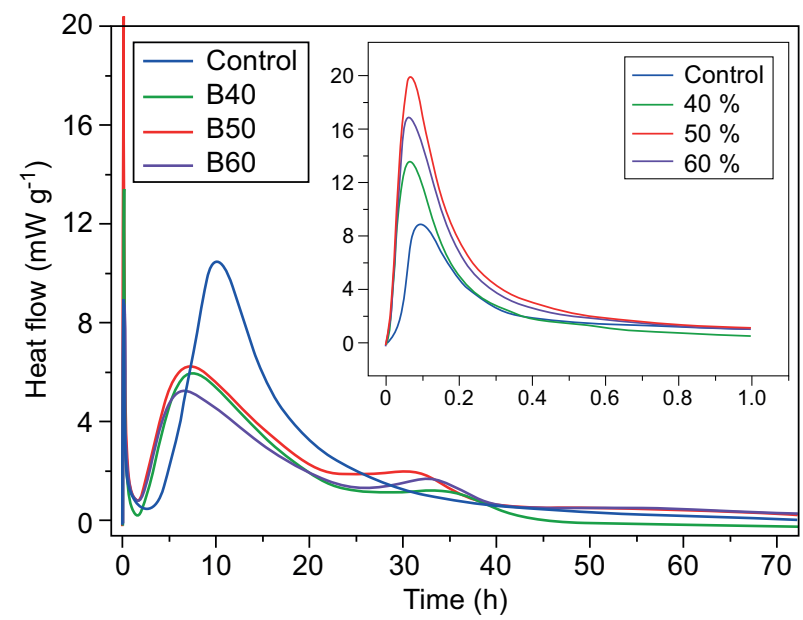

c)

Figure 5. The thermal analysis of the $\mathrm{LC}^{3}$ pastes: a) and b) the thermogravimetric analysis of the B50 sample at 3, 7, 28 days; c) the heat release. (Continue on next page) 
Li Q., Wang H., Hou P., Chen H., Wang Y., Cheng X.

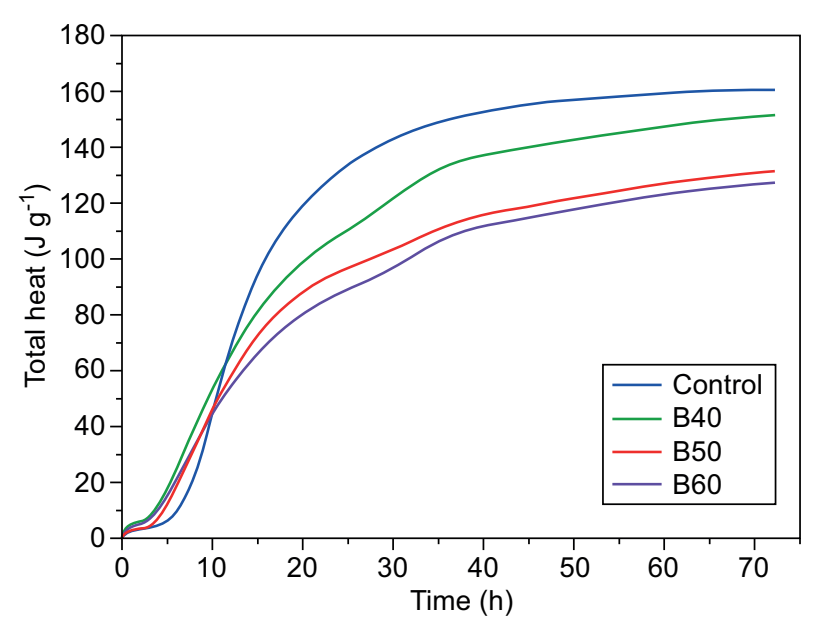

d)

Figure 5. The thermal analysis of the $\mathrm{LC}^{3}$ pastes: d) the cumulative heat released. carbonate with the monosulfoaluminate to form hemi/ mono-carboaluminates [7]. But the total heat evolution of the $\mathrm{LC}^{3}$ system is lower than the OPC one due to the dilution effect [5]. The heat release of the B50 group is $14 \%$ lower than the $\mathrm{OPC}$ one, and the $\mathrm{B} 40$ group is $25 \%$ lower than the OPC one, which explains the poor development of the compressive strength of the $\mathrm{LC}^{3}$ mortar at the early age. The dilution effect of $\mathrm{LC}^{2}$ makes the total heat evolution decrease significantly.

\section{Sample morphology}

The sample morphology shows the structural characteristics of the $\mathrm{LC}^{3}$ paste. Compared to B50-at 3 days (a) and the control at 3 days (d), B50 contains more needle-like AFt, and some unreacted metakaolin, which is in agreement with the XRD results. At seven days, the bulk cement paste contains some hexagonal $\mathrm{Ca}(\mathrm{OH})_{2}$, and the structure is denser than that of B50.

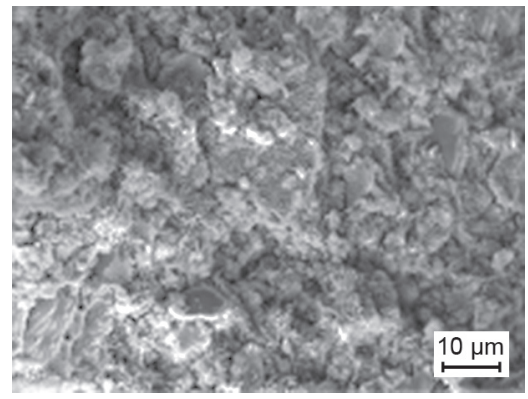

a) B50 - 3 days

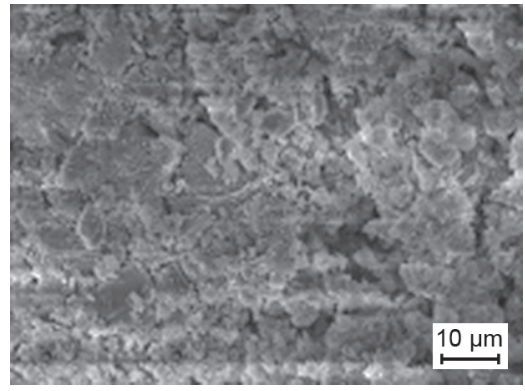

d) Control -3 days

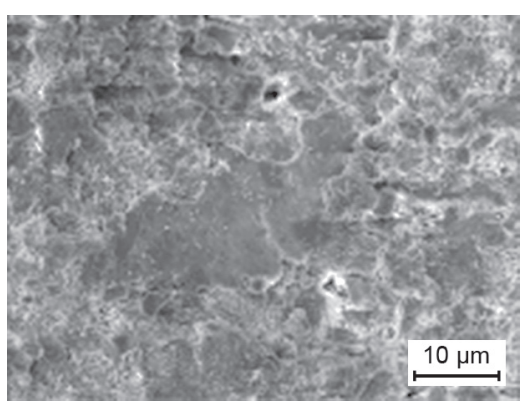

b) B50 - 7 days

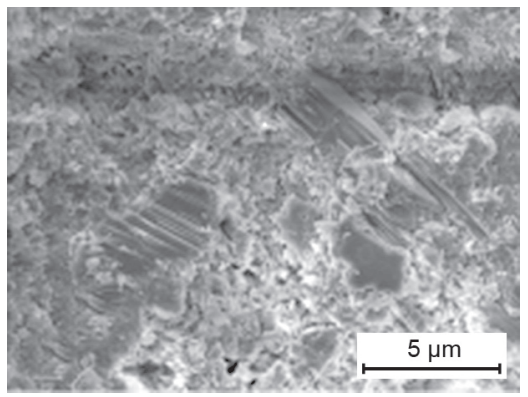

e) Control - 7 days

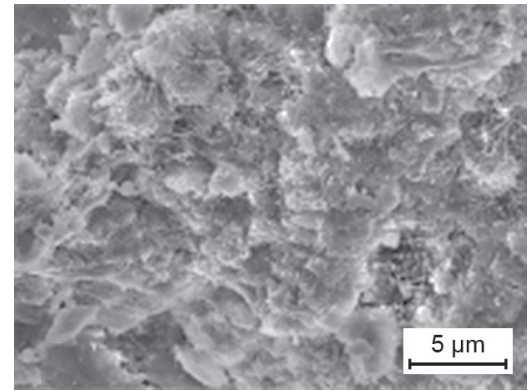

c) B50 - 28 days

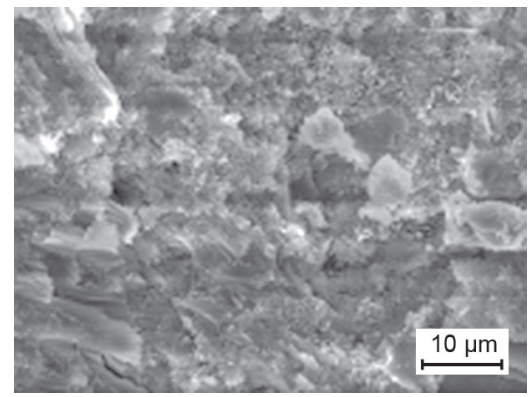

f) Control - 28 days

Figure 6. The morphological images of B50 and OPC (control group) at 3, 7, 28 days.

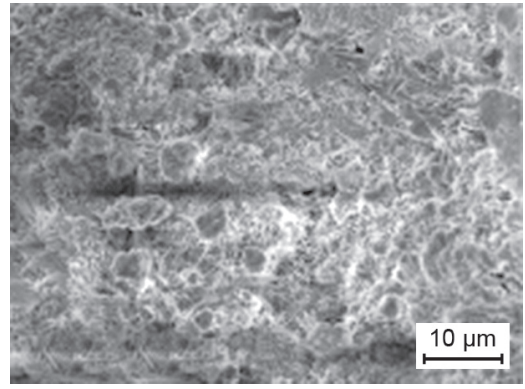

a) B40 - 3 days

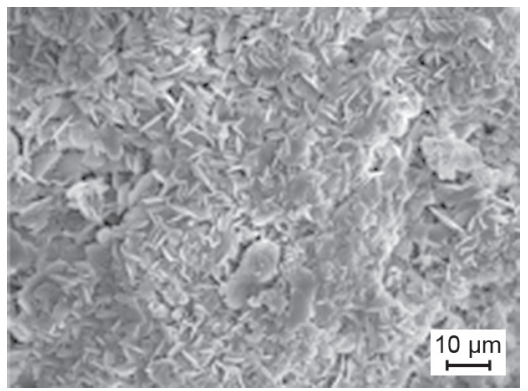

b) B60 - 7 days

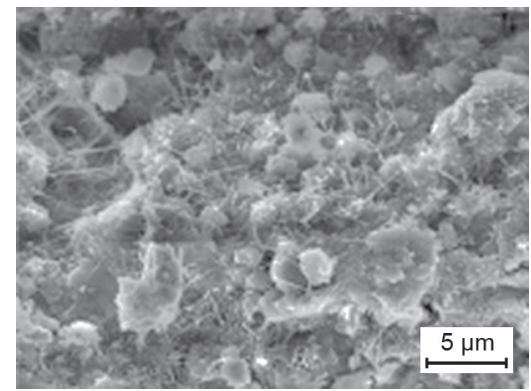

c) B60 - 28 days

Figure 7. The morphological images of $\mathrm{B} 40$ and $\mathrm{B} 60$ at 3, 7, 28 days. 
The microstructure of the cement gradually compacts in the late age. At 28 days, compared with the control group, the $\mathrm{LC}^{3}$ system has more holes and cracks, which means it has a relatively loose microstructure.

Figure 7 shows some different hydration products of $\mathrm{B} 40$ and $\mathrm{B} 60$ at 3, 7, 28 days. At 3 days, B40 has a large number of unhydrated particles and AFt. It could be observed that some flower-like AFm are shown in Figure $7 \mathrm{~b}$, and some needle-like AFt are shown in Figure $7 \mathrm{c}$. These crystalline aluminate phases improve the flexural strength of the $\mathrm{LC}^{3}$ mortar, which is in accordance with the reference [26]. The improvements of $\mathrm{LC}^{2}$ depends on the pozzolanic activity of the calcined clay, the formation of the crystalline aluminates and the pore structures, etc. $\mathrm{LC}^{2}$ can react with the calcium hydroxide to form more $\mathrm{C}-\mathrm{A}-\mathrm{S}-\mathrm{H}$ gels. Besides, the crystalline aluminates can be accumulated in the unhydrated spaces, and affect the changes of the pore structure of the $\mathrm{LC}^{3}$ mortar, resulting in changes in mechanical properties at the macro-scale.

\section{CONCLUSION}

In this paper, low quality calcined clay is shown to have the potential to be a supplementary cementitious material. The relationship between the mechanical properties and the microstructure of the $\mathrm{LC}^{3}$ was explored through various measurements, such as XRD, TG and SEM. It was concluded that:

- $\mathrm{LC}^{2}$, as a new supplementary cementitious material, can improve the flexural strength of $\mathrm{LC}^{3}$ mortars even at a high clinker substitution, although it can also decrease the compressive strength. Increasing the $\mathrm{LC}^{2}$ content makes the compressive strength of the $\mathrm{LC}^{3}$ mortars decrease due to the dilution effect, but can enhance the flexural strength up to $120 \%$. The $\mathrm{LC}^{3}$ mortars have a great capability of improving the anticracking property of plastering mortars.

- Calcined clay has a pozzolanic activity which allows it to react continuously with the calcium hydroxide to form $\mathrm{C}-\mathrm{A}-\mathrm{S}-\mathrm{H}$. When the $\mathrm{LC}^{3}$ paste has hydrated for 28 days, the mass percentage of $\mathrm{Ca}(\mathrm{OH})_{2}$ is as low as $4 \%$.

- The aluminate phases in the calcined clay reacted with the limestone powder to form more carbonate-based AFm phases, including $\mathrm{Hc}$ and $\mathrm{Mc}$, thus, it promoted the development of the strength of the $\mathrm{LC}^{3}$ mortars in the later period. More crystalline hydration products like needle-like ettringites and hexagonal-plate AFm phases are generated in the $\mathrm{LC}^{3}$ system, and also intertwined with the cementitious matrix which improves the flexural strength of the $\mathrm{LC}^{3}$ mortars.

\section{Acknowledgments}

Funding for this project was provided by the National Key R\&D Programme of China (2016YFE206100) and the National Natural Science Foundation of China
(No. 51802112 and No. 51761145023). Supports from the 111 Project of International Corporation on Advanced Cement-based Materials (No. D17001) and the Taishan Scholars Programme are greatly appreciated. The funding is also supported by the Opening Project of State Key Laboratory of Green Building Materials.

\section{REFERENCES}

1. Antoni M., Rossen J., Martirena F., Scrivener K. (2012): Cement substitution by a combination of metakaolin and limestone. Cement and Concrete Research, 42, 1579-1589. doi: 10.1016/j.cemconres.2012.09.006

2. FrancoisA., ScrivenerK.(2018): Investigation of the calcined kaolinite content on the hydration of Limestone Calcined Clay Cement $\left(\mathrm{LC}^{3}\right)$. Cement and Concrete Research, 107, 124-135. doi: 10.1016/j.cemconres.2018.02.016

3. Sayanam R.A., Kalsotra A., Mehta S.K. (1989): Studies on thermal transformations and pozzolanic activities of clay from Jammu region (India). Journal of Thermal Analysis, 35(1), 99-106. doi: 10.1007/BF01914268

4. Peiyu Y., Xiao Q., Wenyan Y., Jiang P. (2001): The semiquantitative determination and morphology of ettringite in pastes containing expansive agent cured in elevated temperature. Cement and Concrete Research, 31(9), 1285-1290. doi: 10.1016/S0008-8846(01)00563-4

5. Chakchouk A., Sameta B., Mnif T. (2006): Study on the potential use of Tunisian clays as pozzolanic material. Applied Clay Science, 33, 79-88. doi: 10.1016/j.clay.2006. 03.009

6. Ambroise J., Pera J. (1985): Hydration reaction and hardening of calcined clay and related minerals V. Extension of the research and general conclusions. Cement and Concrete Research, 15(2), 261-268. doi: 10.1016/00088846(85)90037-7

7. Sanchez B.S., Favier A., Rosa D.E., Sanchez M., Heierli U., Scrivener K., Martirena F. (2016): Assessing the environmental and economic potential of Limestone Calcined Clay Cement in Cuba. Journal of Cleaner Production, 124, 361-369. doi: 10.1016/j.jclepro.2016.02.125

8. Rodrigo F., Martirena F., Scrivener K. (2011): The origin of the pozzolanic activity of calcined clay minerals: a comparison between kaolinite, illite and montmorillonite. Cement and Concrete Research, 41 (1), 113-122. doi: 10.1016/j.cemconres.2010.09.013

9. Francois A., Ruben S., Adrain A., Mohsen B.H., Scrivener K. (2016): Development of a new rapid, relevant and reliable (R3) test method to evaluate the pozzolanic reactivity of calcined kaolinitic clays. Cement and Concrete Research, 85,1-11. doi: 10.1016/j.cemconres.2016.02.015.

10. Khatib J., Wild M.S. (1996): Pore size distribution of metakaolin paste. Cement and Concrete Research, 26(10), 1545-1553. doi: 10.1016/0008-8846(96)00147-0

11. Tironi A., Castellano C, Bonavetti V.L. (2016): Kaolinitic calcined clays-Portland cement system: Hydration and properties. Construction and Building Materials, 64(30), 215-221. doi: 10.1016/j.conbuildmat.2014.04.065

12. Frias M., Cabrera J. (2000): Pore size distribution and degree of hydration of metakaolin-cement pastes. Cement and Concrete Research, 30(4), 561-569. doi: 10.1016/ S0008-8846(00)00203-9 
13. Florian D., Frank W., Barbara L. (2012): Hydration of Portland cement with high replacement by siliceous fly ash. Cement and Concrete Research, 42, 1389-1400. doi: 10.1016/j.cemconres.2012.06.009

14. Shekarch A., Bonakdar M., Balkhsh A. (2010): Transport properties in metakaolin blended concrete. Construction and Building Materials, 24, 2217-2223. doi: 10.1016/j. conbuildmat.2010.04.035

15. Badogiannis E., Kakali G., Dimopoulou G., Chaniotakis E., Tsivilis S. (2005): Metakaolin as a main cement constituent Exploitation of poor Greek kaolins. Cement and Concrete Composites, 12(27), 197-203. doi: 10.1016/j. cemconcomp.2004.02.007

16. Wild S., Khatib J., Jones A. (2006): Relative strength of cement and cement hydration in superplasticised metakaolin concrete. Cement and Concrete Research, 26(10), 1537-1544. doi: 10.1016/0008-8846(96)00148-2

17. Marco P. (2015). Recycled Aggregate Concretes. CRC Press.

18. Irbe L., Beddoe R.E., Heinz D. (2019): The role of aluminium in $\mathrm{C}-\mathrm{A}-\mathrm{S}-\mathrm{H}$ during sulfate attack on concrete. Cement and Concrete Research, 116, 71-80. doi: 10.1016/j. cemconres.2018.11.012

19. Lothenbach B., Saout G.L., Gallucci E. (1979): Influence of limestone on the hydration of Portland cements. Dento Maxillo Facial Radiologym, 8(1), 42-49. doi: 10.1016/j. cemconres.2008.01.002

20. Shi Z., Geiker M.R., Weerdt K.D., Østnor T.A., Lothenbach B., Winnefeld F., Skibsted J. (2017): Role of calcium on chloride binding in hydrated Portland cement-metakaolin-limestone blends, Cement and Concrete Research, 95, 205-216. doi: 10.1016/j.cemconres.2017.02.003

22. Hoshino S., Yamada K., Hirao H. (2006): XRD/Rietveld Analysis of the Hydration and Strength Development of Slag and Limestone Blended Cement. Journal of Advanced Concrete Technology, 4(3), 357-367. doi: 10.3151/jact. 4.357

23. Burak F., Tosum K., Baradan B. (2016): The effect of fly ash and limestone fillers on the viscosity and compressive strength of self-compacting repair mortars. Cement and Concrete Research, 36(39), 1719-1726. doi: 10.1016/j. cemconres.2006.04.002
24. Dhandapani Y., Santhanam M. (2017): Assessment of pore structure evolution in the limestone calcined clay cementitious system and its implications for performance. Cement and Concrete Composites, 84, 36-47. doi:.1016/j. cemconcomp.2017.08.012

25. Avet F., Boehm-Courjault E., Scrivener K. (2019): Investigation of $\mathrm{C}-\mathrm{A}-\mathrm{S}-\mathrm{H}$ composition, morphology and density in Limestone Calcined Clay Cement $\left(\mathrm{LC}^{3}\right)$. Cement and Concrete Research, 115, 70-79. doi: 10.1016/j.cemconres. 2018.10.011

26. Matschei T., Lothenbach B., Glasser F.P. (2007): The AFm phase in Portland cement. Cement and Concrete Research, 37, 118-130. doi: 10.1016/j.cemconres.2006.10.010

27. Mullre A.C.A., Scrivener K. (2017): A reassessment of mercury intrusion porosimetry by comparison with1H NMR relaxometry. Cement and Concrete Research, 100, 350-360. doi: 10.1016/j.cemconres.2017.05.024

28. Avet F., Scrivener K. (2018): Investigation of the calcined kaolinite content on the hydration of Limestone Calcined Clay Cement $\left(\mathrm{LC}^{3}\right)$. Cement and Concrete Research, 107, 124-135. doi:10.1016/j.cemconres.2018.02.016

29. Gmür R., Thienel K., Beuntner N. (2016): Influence of aging conditions upon the properties of calcined clay and its performance as supplementary cementitious material. Cement and Concrete Composites, 72, 114-124. doi: 10.1016/j.cemconcomp.2016.05.020

30. Scrivener K., Martirena F., Bishnoic S., Maity S. (2018): Calcined clay limestone cements (LC3). Cement and Concrete Research, 114, 49-56.doi: 10.1016/j.cemconres. 2017.08.017

31. Okoronkwo M.U., Glasser F.P. (2016): Compatibility of hydrogarnet, $\mathrm{Ca} 3 \mathrm{Al} 2(\mathrm{SiO} 4) \mathrm{x}(\mathrm{OH}) 4(3-\mathrm{x})$, with sulfate and carbonate-bearing cement phases: $5-85^{\circ}$. Cement and Concrete Research, 83, 86-96. doi:10.1016/j.cemconres. 2016.01.013

32. Baquerizo L.G., Matschei T., Scrivener K., Saeidpour M., Wadsö L. (2015): Hydration states of AFm cement phases. Cement and Concrete Research, 73, 143-157. doi: 10.1016/j.cemconres.2015.02.011 